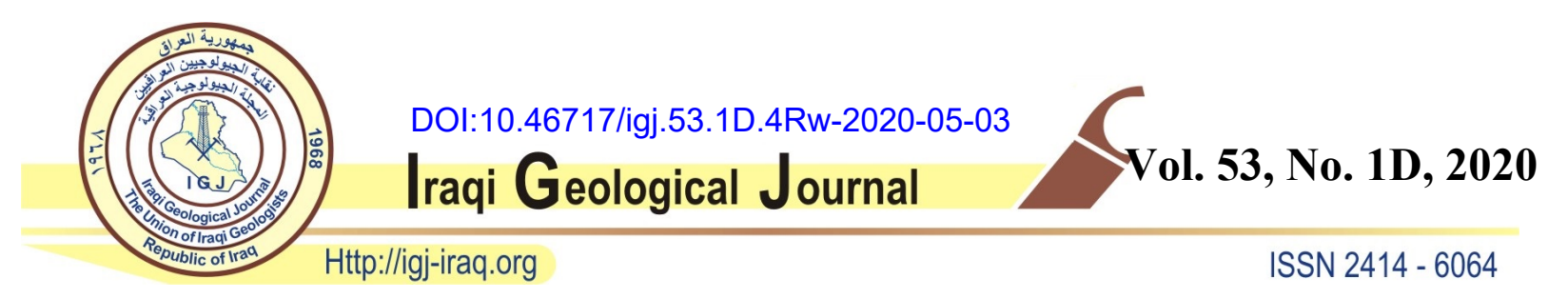

\title{
DEPOSITIONAL ENVIRONMENTS, FACIES DISTRIBUTION, AND POROSITY ANALYSIS OF YAMAMA FORMATION IN MAJNOON OILFIELD. SEQUENCE STRATIGRAPHIC APPROACH
}

\author{
${ }^{1}$ Rami M. Idan*, ${ }^{1}$ Amani L. M. Salih, Omar N. A. Al-Khazraji and ${ }^{1}$ Marwah H. Khudhair \\ ${ }^{1}$ Department of Geophysics, College of Remote Sensing and Geophysics, Al-Karkh University of Science, \\ Baghdad, Iraq \\ *E-mail: ramisc3@gmail.com \\ Received: 31 May 2019; accepted: 28 March 2020
}

\begin{abstract}
Due to the importance of petroleum exploration and production in the oil industry and developments. Therefore, this study targets one of the more important reservoir rocks in Iraq, which it Yamama Formation in the Majnoon oilfield, southern Iraq. The facies distribution showed that the formation was deposited on a ramp platform. Seven main carbonate facies were distinguished in the studied area. Based on these facies, Yamama Formation was represented to deposit on a ramp setting, that consist of different sedimentary environments. The main depositional environments represented by the shoal, middle - outer ramp and deep outer ramp environments. Eventually, the Yamama Formation is divided into two main sequences. The lower part of the formation was a regression phase that deposited highstand system tracts, named Yamama sequence one. The upper was a transgression phase deposited transgressive system tracts named Yamama sequence two. The diagenetic processes showed that the early and late dissolution and cementation are important that affected the reservoir characteristics. Dolomitization is not an active process in the formation. Petrophysical properties represented by primary and as well as secondary porosity were studied and processed to evaluate the reservoir characteristics. The data were obtained from wireline logs and core data from plugs and thin sections. Good reservoir property units were located in a high-energy shoal environment and found in other environments depending on secondary porosity and dissolution processes activity. According to porosity cut-off, the formation was divided into five units that have porosity more than the lower limit of the worthy values. Keywords: Depositional environments; Facies analysis; Majnoon oilfield; Reservoir properties; Sequence stratigraphy; Yamama Formation
\end{abstract}




\section{INTRODUCTION}

The Cretaceous rocks occupy a distinct position within the stratigraphic column in southern Iraq, where the content of this era represents good oil potential rocks. Some of these formations considered as source rocks, while the others were reservoirs with high oil potentiality (AlGailani, 1991 and Handhal, et al., 2020). On the other hand, data acquisition and analysis has become one of the cornerstones for the proper and effective projects, especially those that deal with continuous changes and various formations such as oil industries. Therefore, this study targets one of the more important reservoir rock in Iraq, which is Yamama Formation. Due to the good oil potentiality of the Cretaceous rocks in general, and the Yamama Formation in particular, it attracted the attention of many researchers in the oil companies of the central and southern regions of Iraq (Al-Ameri et al., 2012 and Al-Khafaji et al., 2019).

This study is intended to complement previous studies of the relationship between sedimentary environments and diagenetic processes and their effect on the petrophysical properties (Idan, 2004). The trends of increasing or decreasing of these properties using the sequence stratigraphy analysis of Yamama Formation is the main target of this study. The formation occurs in the upper Berriasian-Aptian rock package. This package comprises the environments from shallow tidal flat to the deeper basin environments represented by the Shuiaba, Zubair, Ratawi, Yamama, Sarmord, and Lower Balambo formations (Buday, 1980). Yamama Formation is composing generally of limestone, with some thin dolomitic intervals, as well as narrow shale laminae have been described. Moreover, (Sadooni, 1993) reported in the Yamama Formation some anhydrite intervals in western parts of its basin.

Yamama Formation overlies the underneath Sulaiy Formation in a conformable manner. The latter is a Jurassic-Lower Cretaceous carbonates composes of mud-dominated argillaceous limestone and contains the small-size benthic foraminifera. Yamama Formation changes upward gradually into Ratawi Formation. Ratawi Formation is a heterogeneous package of dirty limestone, shale, siltstone, and sandstone. The Ratawi Formation can be considered as a seal interval of the Yamama reservoir rocks (Jassim and Buday, 2006).

Zubair Formation that characterizes regressive deltaic facies parts of the transgressive carbonate period terminates the Sulaiy, Yamama, and Ratawi formations. Zubair facies (and maybe upper Ratawi shale) considered as the clastic invasion of this cycle (Sadooni, 1993). To support this standpoint, (Jassim and Buday, 2006) indicated that the Mesopotamian basin subjected to several open marine events. These events allow the deposition of the shallow marine carbonates along with the lower Cretaceous platform. The Sulaiy and Yamama formations are deposited during the transgression phase, while the Ratawi Formation was the highstand phase of this sequence. 
The studied oilfield is located northeast of Basrah city. The field delineates a 770740 dividing line and a 3470342 incline (Fig.1). The field of study is a subsurface fold of a simple and asymmetric axis, with its western side being the least inclined on its eastern side (Abbas and Mahdi, 2020). The dimensions of the field were about $24 \mathrm{~km}$ long, $4 \mathrm{~km}$ wide, and a structural enclosure of about $300 \mathrm{~m}$. The thickness of the Yamama Formation in the studied oilfield ranged from 300 to $350 \mathrm{~m}$ (Al-Zaidy and Al-Mafraji, 2019). Tectonically, the field of study locates within the sedimentary depression of the Mesopotamia foredeep, which is part of the unstable shelf according to the divisions (Buday and Jassim, 1987, Idan, 2017, and Idan et al., 2019).

The main goal of this study is to find a relationship between the reservoir properties and sedimentary environments in carbonate rocks, concerning the effects of the diagenesis processes. Moreover, the petrophysical characterizations of the reservoir intervals are a good utility to develop oil exploration and production in the old oilfields.

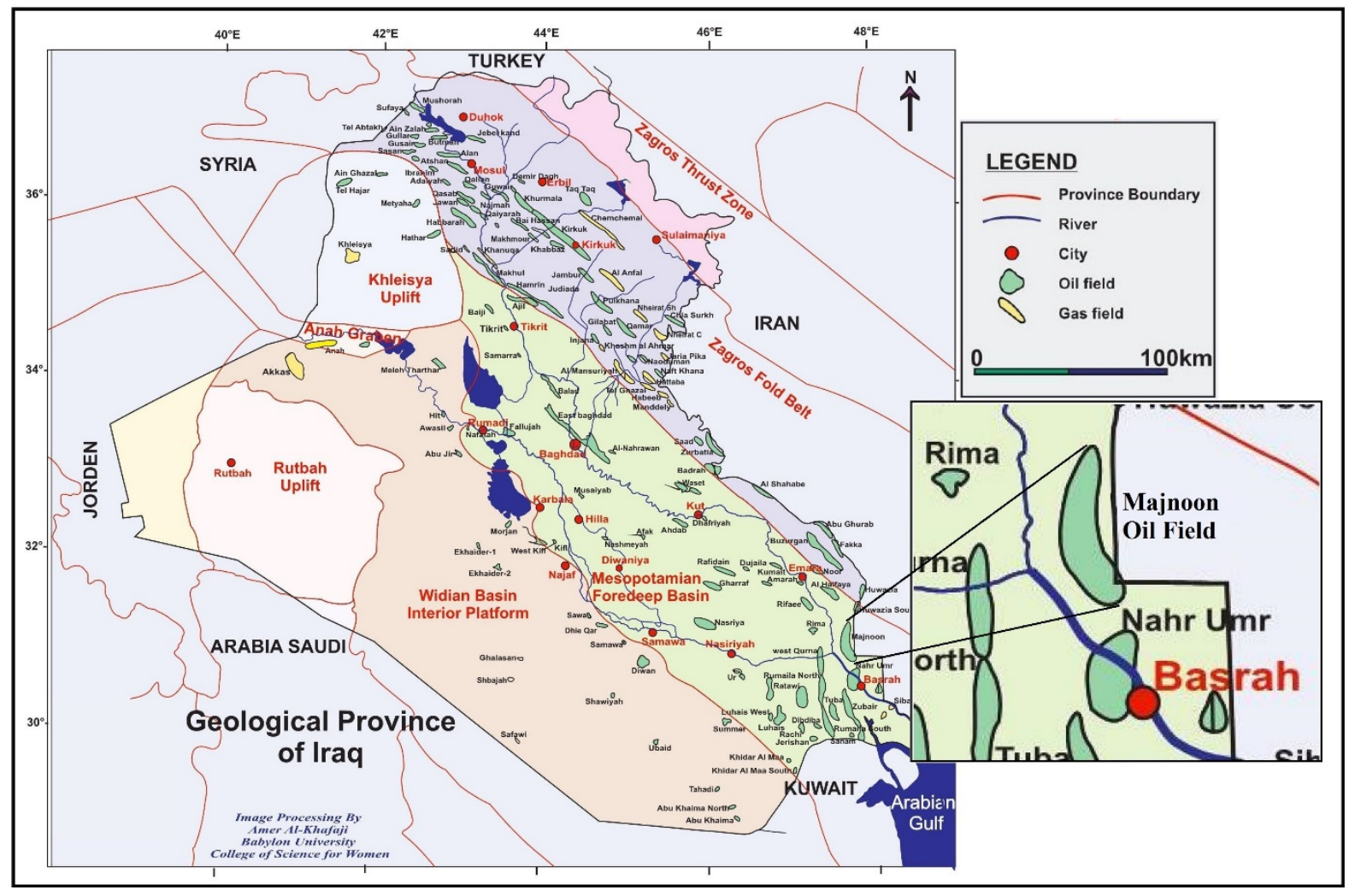

Fig. 1. Location map of the Majnoon oilfield in southern Iraq (after Al-Ameri et al., 2011)

\section{MATERIALS AND METHODS}

This study was based on subsurface data approved by the Petroleum Exploration Company. Five wells were selected at the top and the flanks of the Majnoon structure: $\mathrm{Mj}-2, \mathrm{Mj}-4, \mathrm{Mj}-9$, $\mathrm{Mj}-11$, and $\mathrm{Mj}-12$. The row data were collected from the final geological reports of the studied wells, which contain the plugs and thin sections that were identified, as well as the top, bottom 
and the thickness of the formation, were determined for each well. On the other hand, the results of the porosity and permeability from plugs were obtained for the study field to calculate the porosity cut-off.

About $370 \mathrm{~m}$ of cores description is available to the five studied wells. The description identifies general physical properties such as hardness, colour, oil staining, sedimentary structures, pore type, fossils and stylolite. Thin section analysis by polarized microscope, resulted in the petrographic description, identification and classification of microfacies, as well as identification of diagenetic processes. The number of slides was more than 450 of cores and cuttings slides. Well logs analysis used to predict the relationship between the porosity and permeability and the effects of the sedimentary environments and diagenesis in term of decreasing or increasing the reservoir properties.

\section{TECTONIC SETTING HISTORY OF YAMAMA BASIN}

The integration of the divergence of Indian and Arabian plates at the end of the Paleozoic and during the Triassic and Jurassic periods in the early Cretaceous period. This divergence was the reason for the formation of a Passive margin accompanied by the opening of the great sea NeoTythes. This characterizes the Yamama basin in the study area, which enabled the preservation of sediments (Sharland et al., 2001 and Faisal and Mahdi, 2020). This plate divergent led to the development of large basins in the Broad Intra-Shelf Basins along with the platform that governed the regional distribution of sedimentary facies (Christian, 1997, Idan et al., 2015a and Idan and Faisal, 2019). These basins were influenced by the Lystric faults, which led to rapid differential subsidence, and as a result, formed rift continental margins (Horsts). Above horsts, an isolated platform has grown, whilst adjacent to deep-seated areas that were submerged beneath the ocean (Molina, 1985). This tectonic setting led to a special type of stratigraphy where the study area was located on one of these horsts. While the adjacent areas, such as the wells of Seeba, Kumait, and the adjacent contacts of Majnoon oilfield in Iran were located in deep subsiding basins (Sadooni, 1993, Al-Musawi et al., 2019, and Abd Aoun and Mahdi, 2020), this type of basin is so-called Extensional or Rift Basin.

Deep marine environments in most directions surround these high-energy isolated horsts. These platforms (horsts) usually have a flat-topped shape with an oolitic and/or peloidal dominant facies and ranging from 7-10km in length (Hand ford and Locks, 1993). This isolated platform described by mature carbonates sediments throughout all the stages of formation. This structural situation and sea-level changes have governed the sequence evolution of Yamama Formation and influenced the patterns of the sediments, which had a great impact on the Yamama platform development, which was isolated from the continent detrital invasion that helped to grow the oolitic and peloidal facies. 


\section{SEDIMENTARY ENVIRONMENTS AND MICROFACIES DISTRIBUTION}

The distribution of sediments of Yamama platform depends on its position within that basin. Mud-supported sediments, which are dominated by fine granules, organic matter and pyrite, as well as the algal deposits in the outer slope environment, which is below the level of the Storm Wave Base (SWB). The inner ramp sediments, located between the shoreline and the Fair Weather Wave Base (FWWB), are high-energy and contain peloids, oolites and bioclasts, and there are lagoon facies. Reworked facies that contain a mixture of materials which reflect environments of variable energy agents. This change in energy agents resulted from the impact of storms (Tempestite), which determine between SWB and FWWB in the middle ramp facies (Read, 1985, Burchette and Wright, 1992, and Lopez and Valera, 2012, Idan et al., 2015b). As well as, the composition of Yamama was classified depending on Denham (1962) modified by Embry and Clovan (1972) as:

\section{Mudstone Microfacies}

This microfacies occupies intervals of a thickness not exceeding one meter, sometimes occur at the formation bottom, especially at the relatively deeper wells ( $\mathrm{Mj}-2, \mathrm{Mj}-11$, and $\mathrm{Mj}-12)$. As well as the facies located in a narrow interval within the formation tops in the wells $\mathrm{Mj}-11$ and Mj-9. This facies composes of black argillaceous micrite with vuggy porosity that develops sometimes into channel porosity (cf. Lucia, 1995 and 2001) as illustrated in Plate 1, A, but in general, this facies represents a permeability barrier layer separates the main reservoir units. Late cementing diageneses partially affected this facies with drusy cement (Flugel, 2010). Whilst dissolution activity that formed vugs and channels was active may be due to the surface exposure (cf. Saller, 1999).

\section{Wackestone Microfacies}

This facies is common in all study wells and has a high prevalence among the others. The micrite in these facies - and Yamama Formation in general - either result from chemical deposition by the activity of bacteria or organic origin due to organic processes by Micritization (Tucker, 1985 and 1993). This microfacies subdivided into the following:

\section{Algal-Bearing Wackestone Microfacies}

These facies are found with red and green algae. Generally, these algae, or their fragments, completely dissolved and filled with one type of cement or more (Plate 1, B). These facies frequently contain shell fragments, coral debris, large benthic foraminifera, and echinoderms fragments and spines, as well as there are shows of pyrite, argillite, and organic matter. The red algae bearing facies are more common in the upper parts of Yamama intervals and indicate deep outer ramp environments (Testa and Bosence, 1998). Whereas the green algae bearing 
facies restricted to the lower parts and indicate relatively shallow low energy environments. Green algae may locate in the lagoon and lagoon shelters or the protected reef flats, in turn; green algae locate in high biodiversity and oxygen-rich environments (Basso and Granier, 2012). It is worth to mention, that genus clypienia jurassica found only in Mj-9, at $3930.5 \mathrm{~m}$ depth (Plate 1, C).

\section{Large Benthic Foraminiferal Wackestone Microfacies}

These facies considered as an important indicator to the continuity of the Transgressive System Tract (TST), due to the content of completely large benthic foraminifera assemblages. The detected foraminifera types were pseudocyclammina, Trocholina, Miliolidae, Naotiloculina ooliithica, pseudochrysalidina conica Everticyclammina, Textularia, Cylindroporella, Valvulina that diagnosed depending on (Brun, 1970). (Plate 1, D for example). This facies assemblage represents the middle to outer ramp environments and/or the deeper parts of the lagoon environments (Yousif et al., 2017). Dolomitization characterizes this facies especially at the sequence boundary, which the later almost represents an erosional surface. High peaks amplitude Stylolite is a good indicator of the elongated sequence boundary that also presents in this facies.

\section{Bioclastic Argillaceous Wackestone-Mudstone Microfacies}

These facies are common at the top and bottom of the formation in all studied wells, while where in the middle parts in $\mathrm{Mj}-2$. The dominant grain in these facies are the bioclasts, which have different origins of benthic foraminifera, echinoderms, pelecypods, coral and algal debris. These facies characterized by the high presence of Argillites and Pyrites, as well as, highly dissolve most or all of the Bioclasts, while the moulds of these bioclasts filled with cement. All these parameters indicate high water depth (Flugel, 2004) and represent the deep outer ramp environments.

\section{Packstone Microfacies}

In general, these facies reflect relatively high-energy environments that represent the inner and middle ramp setting. The micritization process in most zones affects this facies; this facies can be subdivided into:

\section{Peloidal Packstone Microfacies}

This facies located in the lower parts of the Yamama section at the depth of 3970-3993 m in Mj-9, while it represents the bottom of the formation in $\mathrm{Mj}-4$, at the interval $4096-4040 \mathrm{~m}$. The facies also represents the sheet-like grain supported facies of the shoals' environment from the inner ramp as in the lower part of the $\mathrm{Mj}-11$. Otherwise, it locates as aggradational facies in $\mathrm{Mj}$ 12 and $\mathrm{Mj}-2$, as a sign of the start of the transgression phase. This facies represents the Shoal Environment according to (Burchette and Wright, 1992). The peloids are usually had a 
biological origin, argillaceous, highly micrtitized, and ranged of $0.05-0.2 \mathrm{~mm}$ in length. They are very granulated and sometimes contained argillite, Plate 2,A. Fossils are always foraminifera such as Valvulina, Trocholina and rarely Pseudocyclammina, as well as red and green algae and bioclasts that represent the barrier and back-barrier environments (cf. Vaziri et al., 2012).

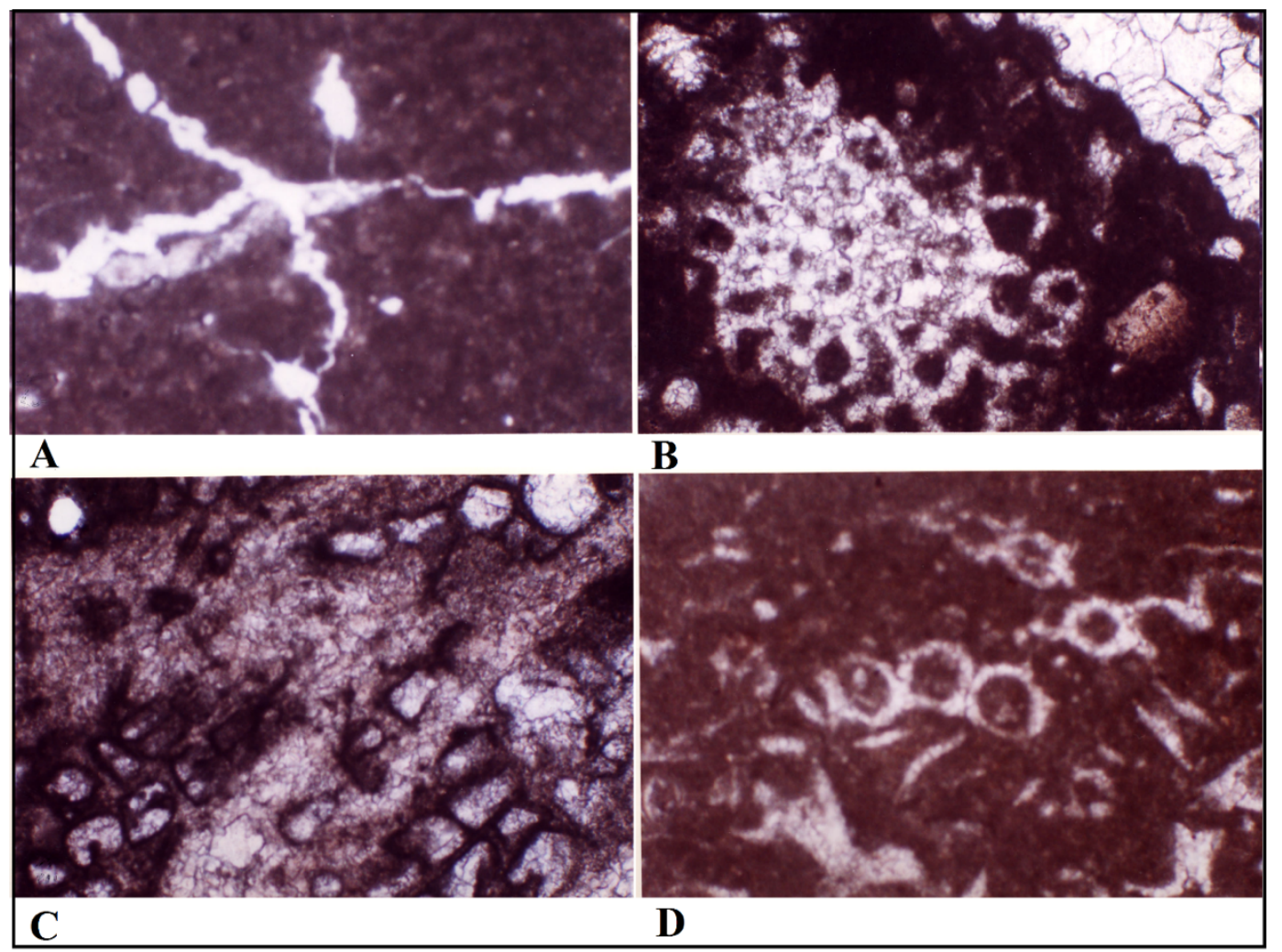

Plate 1: (A) Mudstone microfacies: Late granular cement affecting the secondary porosity. Well Mj-2, depth 3922m. 4X magnification. (B) Wackestone - Packstone facies: Permocalculus and shell moulds that cemented with equant and blocky cement. Well Mj-2, depth 3918m. 4X magnification. (C) Packstone facies: Clypiena jurassica with drusy cement inside the fossil. Well Mj-9, depth 3930.5. 4X magnification. (D) Wackestone facies: fully cemented Actinoporella.

Well Mj-2, depth 3921m. 4X magnification

\section{Reworked Material Packstone- Wackestone Microfacies}

These facies contain different sizes, poorly sorted materials, and relatively high clay content. Intraclasts begin to increase relative to the presence of peloids whenever move upward in the section of these facies, that indicate deepening upward (Dhihni, 2002, Per. Com.). The intraclasts are highly micritized, angular, irregular, floated in limestone, and may have a biological origin. Foraminifera, such as pseudocyclammina, Trocholina, Textularia, as well as shell fragments, permocalculus, echinoderm, ostracods, corals debris, molluscs, and bioclasts are present with frequently the absence of cementation processes. These deposits are located in 
M-4 at the depth 3970-3993m, where overlie on the lagoon facies. These deposits represent deepening Upward (Idan, 2004) and so-called Tempestite as previously mentioned.

\section{Grainstone Microfacies}

This is the high-energy mature shoal environments, which are close to the shoal shoreline, within the inner slope (Aurell et al., 1998). This microfacies may be divided into three main microfacies. Oolitic grainstone microfacies, locates in the form of local shoals as laminar sheets, while its thickness is not acceding one meter. Oolitic grainstone occurs in the lower parts of the formation and is associated with the presence of the peloidal packstone facies. Otherwise, it interferes with the wackestone facies of the outer ramp environment. This facies present in the upper parts of the Mj-11 where the retrogradation (or backstepping) is due to sea-level rise during the TST, Plate 2, B. This low-diversity facies graduate to a high-diversity highly micritized peloidal grainstone facies that relatively occur in low energy environments than that in oolitic grainstone. These peloids may be attributed to micritization of original ooids or other fossils such as foraminifera and algae. This facies (i.e. shoal belt) was developed and became more mature to the western area, especially toward West Qurna oilfield. As well as the intraclastic grainstone microfacies occurs representing the continuity of the TST, Plates 2-C.

\section{Boundstone Microfacies}

This facies is found in different intervals of the Yamama Formation in the study area, at depths $3940 \mathrm{~m}$ in Mj-9 and $4090 \mathrm{~m}$ in Mj-4 for example. These build-ups locate as patch reefs in these intervals that formed by the Scleractinian coral and may be classified as Bufflestone microfacies (Embry and Clovan, 1972), Plate 2, D.

\section{Floatstone Microfacies}

Floatstone always locates close to the reef body, where the coral and red algae fragments transported in the form of floating debrides that are collected in a clay groundmass, Plate 3, A. These are usually found in the outer ramp environments within the dominant wackestone facies.

\section{Crystalline Carbonate}

The dolomitic facies located in a narrow sheeted lamina not exceeding one-meter thickness. This facies occur in distinctive places of the formation such as erosion surfaces, in different depths, Plate 3, B. The dolomitization process in Yamama Formation is ineffective and not indicated, but refer to certain features such as erosion surfaces, (cf. Saller et al., 1999). 


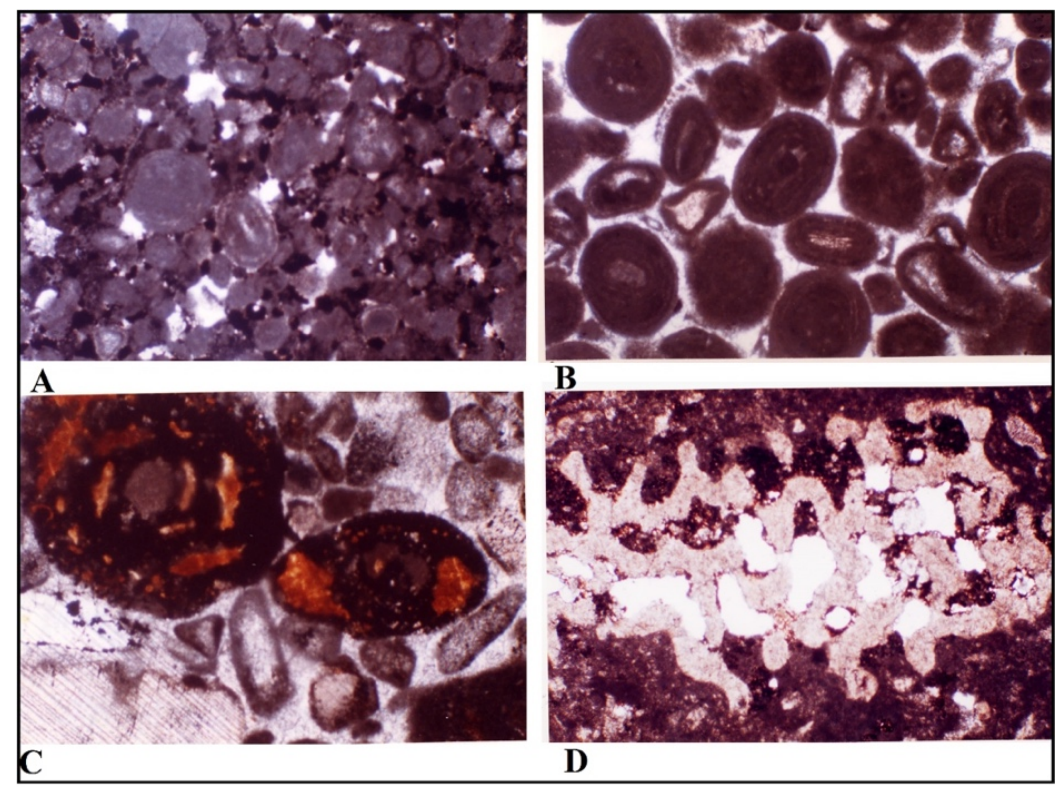

Plate 2. A: Peloidal Packstone facies: Primary porosity with individual Oolite and residual oil. Well Mj-9, depth 3958.5. 4X magnification. B: Oolitic Grainstone facies: Primary porosity. Well Mj-12, depth 4147m. 4X magnification. C: Intraclastic-peloidal in Grainstone facies: Pseudcyclammina with intraparticle porosity contain residual oil and around the genus granular cement within the grains. Well $\mathrm{Mj}-2$, depth $3886 \mathrm{~m}$. 4X magnification. D: Coral debris in Wackestone facies: Primary porosity intra-coral debris. Well Mj-4, depth 4068.1m. 4X magnification

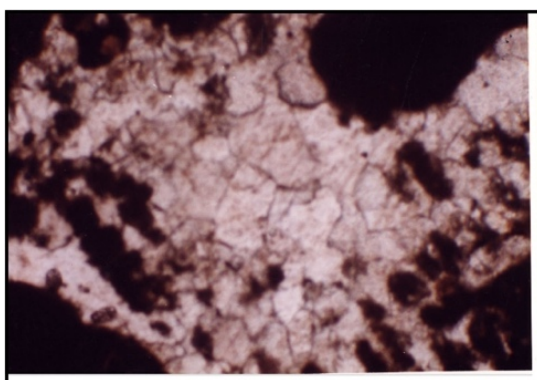

A

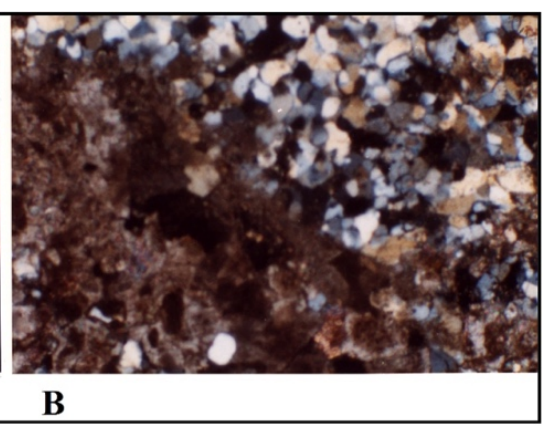

B

Plate 3. A: Floastone facies: completely cemented coral mould. Well $\mathrm{Mj}-2$ 'depth $3833 \mathrm{~m}$. 4X magnification. B: Crystalline carbonate facies: The complete dolomitization of the mudstone. Well Mj-11, depth 3865m. 4X magnification

\section{SEDIMENTARY ENVIRONMENTS}

The facies and texture analysis and fossils components led to distinguish the following sedimentary environments:

\section{Lagoon Environment}

This environment showed in the middle intervals of the Yamama section in Mj-4 and Mj-9. These environments may be interrelated with the environments within the intertidal environments. These environments are subtle and unclear in the study area (Fig.2). 


\section{Shoal Environment}

These environments are characteristic and prevalent in the lower parts of the formation (Fig.3). It is also found in the middle parts of $\mathrm{Mj}-9$ and $\mathrm{Mj}-4$ and locate above the lagoon environment that mentioned above, indicate deepening upward. Further, in the upper parts of the $\mathrm{Mj}-11$, representing the retrogradation (backstepping) of the TST.

\section{Middle- Outer Ramp Environment}

These environments locate especially in the upper part of the formation representing the transgression phase (Figs. 2,3\&4). While they interbedded with shoal environments in the lower part of the formation.

\section{SEQUENCE STRATIGRAPHY}

The results of this study and previous studies indicated that Yamama Formation deposited in a ramp setting (Fig. 4) and can be divided into two rock package of the third-order sequence. These two sequences are separated by a sequence boundary. Yamama Formation is a secondorder sequence age 8my from 143- $136 \mathrm{Ma}$, (Sadooni and Aqrawi, 2000). The formation is divided up into Ys1 and Ys2, for the lower and upper part respectively(Figs. 2\&3). Each sequence is aged approximately 3 my. Ys1 represents a regressive phase of the highstand System Tracts (HST), while Ys2 represents a transgressive phase of transgressive system tracts (TST), separated by relatively prolonged sequence boundary SB.

The systems tracts can be distinguished by defining and identifying sequence boundaries as well as stacking patterns if they are progradation, retrogradation, or aggradation. The identification takes place through facies association relationships and how sediments are distributed, which are the result of sea-level change. The high stand system tract located at the lowermost of the formation below the sequence boundary. The most important characteristics of this system are the resulted accumulation patterns that gradually prograde towards the basin in the form of grain-supported or sand bodies. These bodies are the product of the gradual slope towards the basin because of the retreat of the shoreline. These sand bodies represent shallowing-upward sequences and terminate with lagoon facies as in $\mathrm{Mj}-4$ and $\mathrm{Mj}-9$, or shoal facies as in $\mathrm{Mj}-11$ and $\mathrm{Mj}-12$. These units are thicker than their equivalents in Ys2 because of the shedding in HST. The lower package (Ys1) characterized by a lack of skeletal grains and the dominance of non-skeletal of peloids, as well as oolites in local shoals environments. Whereas, skeletal materials present in the middle and outer ramp environments. In general, Ys1 is grain-supported and characterized by porosity-support diagenesis, where when the sea level retreats freshwater begins dissolution processes. On the other hand, the transgressive system tract (TST) or Ys2 located in the upper part of the formation. The TST characterize by the 
deepening upwards due to the progress of the shoreline toward the land. This package is terminated by the Maximum Flooding Surface (MFS). The MFS herein is hypothetical, which was not indicated in this study. The Ys2 consists of mud-supported retrogradational to aggradational stacking patterns in the relatively deeper wells as Mj-12. Ys2 contains skeletal grains more than Ys1, like red algae and large benthic foraminifera, which were complete fossils. In addition to the growth of isolated buildups that indicate TST in the study area. In Ys2, the diagenesis was porosity decreasing processes as cementation that resulting from the continuous marine drowning of sedimentary facies.

\section{POROSITY ANALYSIS}

The complete analysis distribution of porosity types in the formation, in precise, primary and secondary porosity, provide useful porosity units (PU) determination (Idan, 2004). Five PU were indicated in the Yamama interval based on log interpretation of petrophysical parameters versus depth. In general, the porosity unit interval corresponds to a facies distribution in the rock. However, the PU approach subdivides certain reservoir rock into smaller intervals based on the characterization of the PU.Depending on log analysis, the five main porosity units (PU) were based on the lowest value of porosity cutoff for the wells. Figure (5) shows the profile of these units. The highest levels of porosity were in the well $\mathrm{Mj}-9$, i.e. the top of the structure, which represents high-energy environments (local shoals). While in the flanks (the south and southeast and the north and northeast of the study area), the porosity values have declined.

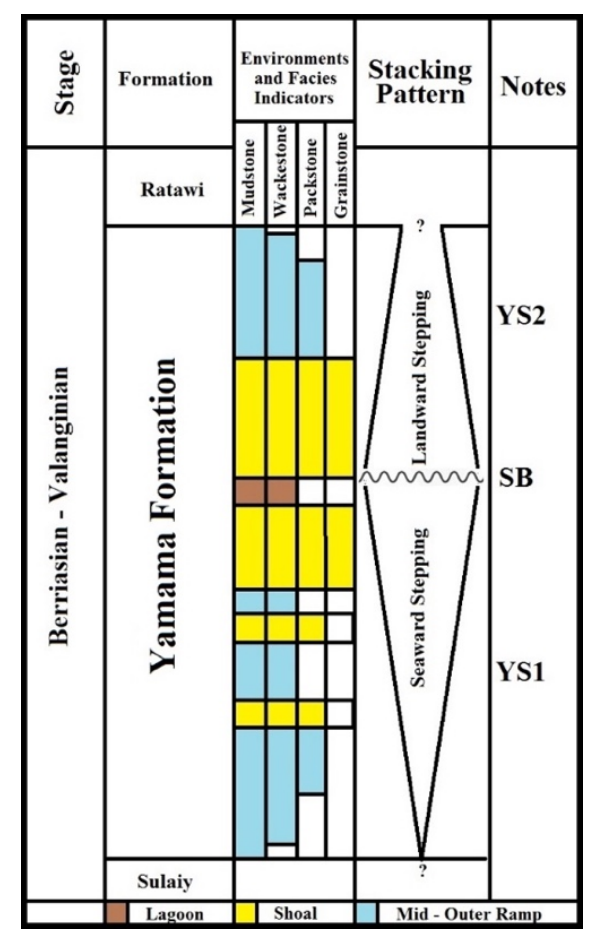

Fig. 2. Illustrate the relationship between stacking patterns and depositional environments with micro-facies as indicators in relatively shallow areas (without scale) 


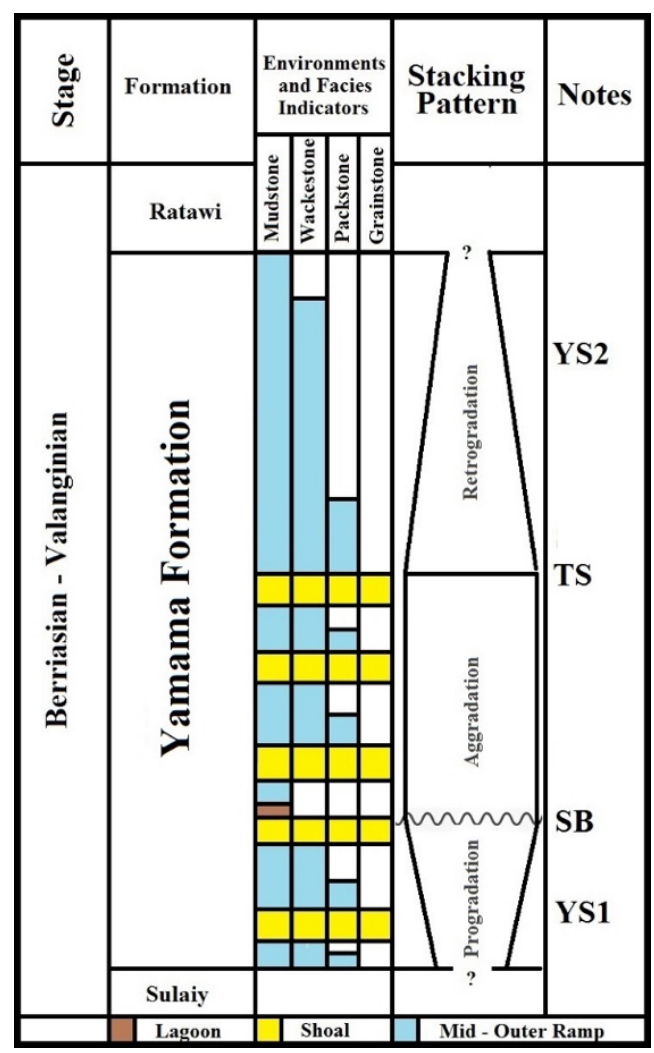

Fig. 3. Illustrate the relationship between stacking patterns and depositional environments with micro-facies as indicators in relatively deep areas (without scale)

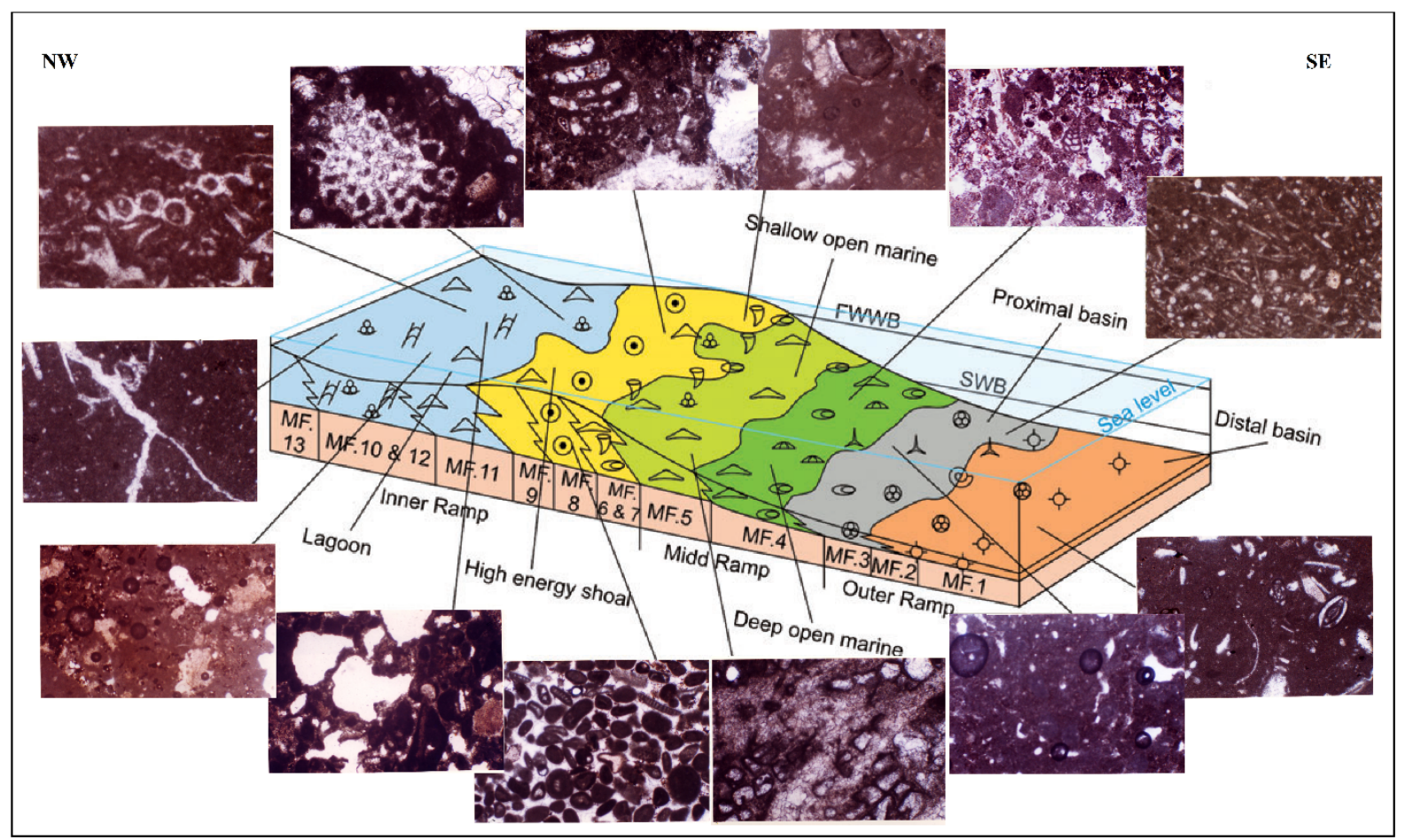

Fi. 4. A schematic model of carbonate ramp environments of the Yamama Formation depended on the facies association and their lateral relationships in respect to the sedimentary environments, modified from Moosavizadeh, et al., 2015 


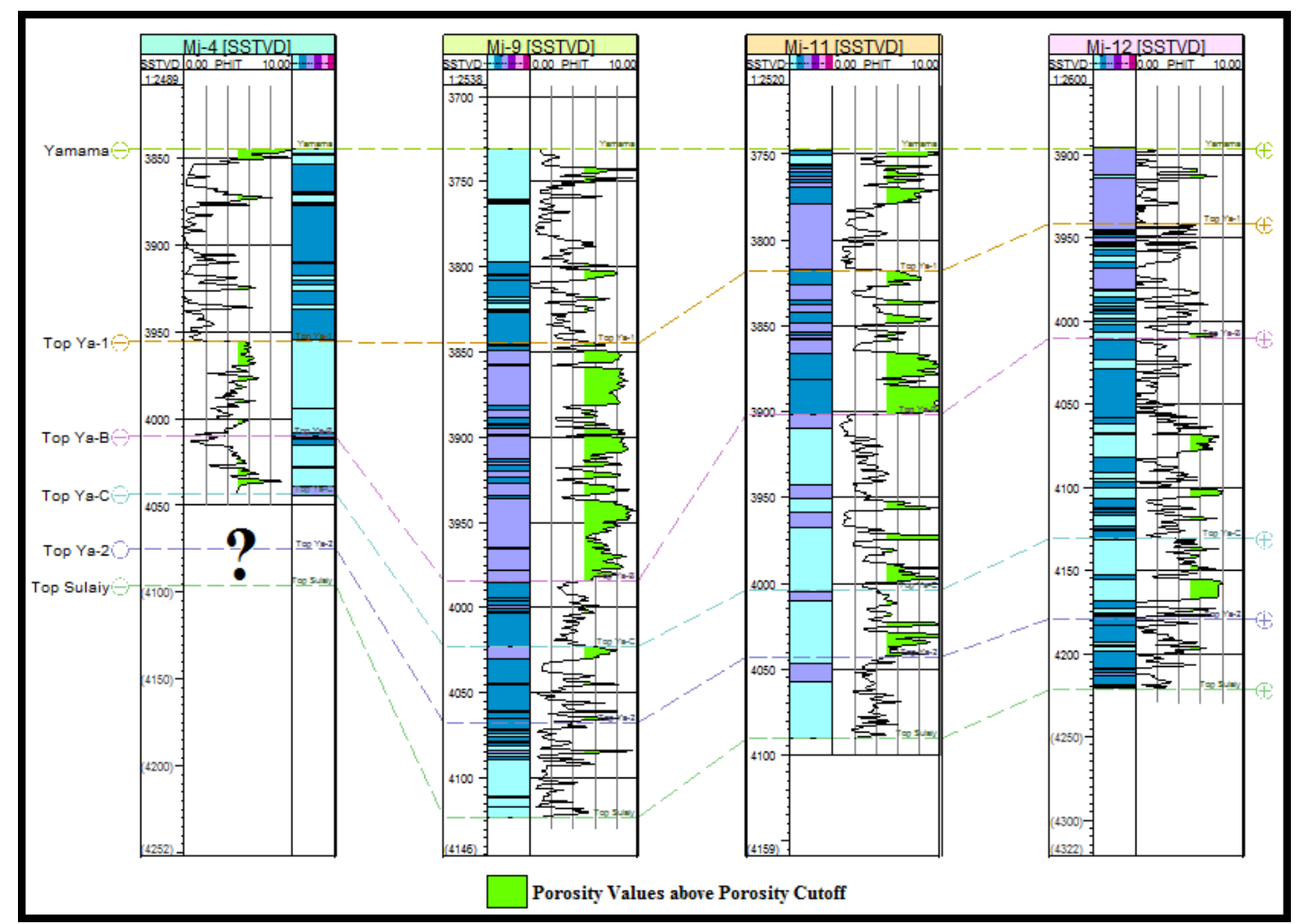

Fig. 5. Illustrate the porosity units (PU) that calculated depending on log interpretation

\section{CONCLUSIONS}

Yamama Formation represents an important reservoir in the south of Iraq. The Yamama Formation in Majnoon oilfield subdivided into two main sequences. These sequences were the lower (Ys1) and upper (Ys2), separated by prolonging sequence boundary (SB). The Yamama basin in the studied area is indicated as a ramp setting in a stable flank of the carbonate platform. The ramp setting effects on the stacking patterns of the Yamama Formation. The oolitic shoal facies were developed and extended especially to the western area toward West Qurna oilfield. These facies occupied the main reservoir intervals that have relatively high porosity and as well as permeability. The lagoon facies existed in the restricted environments of the Yamama platform, represented the final stage of the regression phase, and thus started the sequence boundary period. The main carbonate production located in the inner ramp that has relatively good reservoir facies. The low porosity (and permeability as a result) facies, as indicated from the thin section analysis, were in mudstone or mud-supported intervals that supposed to be deposited in an outer ramp deep environments of the basin toward the eastern parts of eastern Iraqi borders. The log analysis gives five main porosity units based on the lowest values of porosity cutoff for the wells. The highest levels of porosity at the top of the structure, which represent high-energy environments (local shoals). While the flanks in the south and south-east, north and north-east of the study area, porosity values have declined. 


\section{ACKNOWLEDGMENT}

The authors acknowledge Al-Karkh University of Science due to their support. They also acknowledge the Oil Exploration Company and Dr Ghazi Hasan Al-Sharaa for his valuable comments and supports. The editorial board of the Iraqi Geological Journal and the reviewers are also acknowledged due to their support and valuable comments.

\section{REFERENCES}

Abbas, L. K.., and Mahdi, T. A., 2020. Reservoir modeling of Mishrif Formation in Majnoon OilField, Southern Iraq, Iraqi Geological Journal, 53(1B):89-101.

Abd Aoun, G. C., and Mahdi, T. A., 2020. Geological model of Hartha Formation in Majnoon Oilfield, Southern Iraq, Iraqi Geological Journal, 53(1A):48-57.

Al-Ameri, T. K., Al-Jubouri, N. M., Isa, M. J., and Al-Azzawi, R. E., 2012. Hydrocarbons generation potential of the Jurassic-Lower Cretaceous Formation, Ajeel field, Iraq. Arabian Journal of Geosciences, 6(10):37253735. DOI:10.1007/s12517-012-0636-0

Al-Ameri, T. K., Zumberge, J., and Markarian, Z. M., 2011. Hydrocarbons in The Middle Miocene Jeribe Formation, Dyala Region, NE Iraq, Journal of Petroleum Geology, 34(2):199 - 216.

Al-Gailani, M. B., 1991. Hydrocarbon potential of Iraq, Sedimentary Petrology, 1-24.

Al-Khafaji, A. J., Al-Najm, F. M., Al-Ibrahim, R. N., and Sadooni, F. N., 2019. Geochemical investigation of Yamama crude oils and their inferred source rocks in the Mesopotamian Basin, Southern Iraq. Petroleum science and technology, 37(18):2025-2033

Al-Musawi, F. A., Idan, R. M., Salih and A. L. M., 2019. Reservoir properties and facies distribution of Mishrif Formation in Ratawi Oilfield, Southern Iraq. In: Rossetti F. et al., (eds) The structural geology contribution to the Africa-Eurasia Geology: Basement and Reservoir Structure, Ore Mineralisation and Tectonic Modelling. Advances in Science, Technology and Innovation (IEREK Interdisciplinary Series for Sustainable Development). Springer, Cham. doi.org/10.1007/978-3-030-01455-1_25

Al-Zaidy, A. A. H., and Al-Mafraji, T. G. Z., 2019. Geohistory analysis and basin development of the Late Berriasian-Aptian Succession, Southern Iraq. Iraqi Geological Journal, 52(2):36-52.

Aurell, M., Bádenas, B., Bosence, D. W. J., and Waltham, D. A., 1998. Carbonate production and offshore transport on a Late Jurassic carbonate ramp (Kimmeridgian, Iberian basin, NE Spain): evidence from outcrops and computer modelling. In: Wright, V. P. and Burchette, T. P. (eds) Carbonate Ramps. Geological Society, London, Special Publications, 149:137-161.

Basso, D., and Granier, B., 2012. Calcareous algae in changing environments. Geodiversitas, 34(1):5-11.

Brun, L., 1970. Cretaceous microfossils and microfacies from Iraq. ELF-R.E.-internal report.

Buday, T., and Jassim, S. Z., 1987. The Regional Geology of Iraq. Vol. 2, Tectonism, Magmatism and Metamorphism, GEOSURV pub., Baghdad, Iraq. 352 pp.

Buday, T., 1980. The Regional geology of Iraq. Vol. 1, Stratigraphy and Palaeogeography, Dar Al-Kutub Publication House, Mosul. 445 pp.

Burchette, T. P., Wright, V. P., 1992. Carbonate depositional system Sedimentary geology, 79:3-57.

Christian, L. 1997. Cretaceous subsurface geology of the Middle East Region, Geo Arabia, 2(3):239-256.

Embry, Z. R., and Kalovan E. J., 1972. Alate Devonian Reef Tract on northeastern Bank, Islands, northwest territories, Bull. Petrol, Geol., 19:730-781.

Faisal, M. J., and Mahdi, T. A., 2020. Geological model of Mauddud Formation in Badra Oilfield, Iraqi Geological Journal, 53(1A):58-67.

Flügel, E., 2004. Microfacies of Carbonate Rocks, Analysis, Interpretation and Application. $1^{\text {st }}$ edition. Springer, Berlin, $1006 \mathrm{pp}$.

Flügel, E., 2010. Microfacies of Carbonate Rocks, analysis, Interpretation and Application. 2nd edition. Springer, Berlin, $1006 \mathrm{p}$.

Handford, C. R., and Loucks, R. G., 1993. Carbonat depositional platforms to relative sea-level changes, in R. G. Loucks and J. F. Sarg eds. Carbonate sequence stratigraphy, recent development and applications, AAPG Memoir, 57:3-40. https://doi.org/https://doi.org/10.1007/978-3-030-01455-1_25 
Handhal, A. M., Al-Shahwan, M. F., and Chafeet, H. A., 2020. Interpretation of hydrocarbon generation, migration and thermal history Of Mesopotamian Basin Southern Iraq based 1D Petromod software, Iraqi Geological Journal, 53(1B):29-56.

Idan, R. M. 2017. Total organic carbon (TOC) prediction from Resistivity and porosity logs: A case study from Iraq. Bulletin of the Iraq Natural History Museum, 14(3):185-195.

Idan, R. M., 2004. Studying the Petrophysical Characteristics, Sedimentary Environments, and Diagenetic Processes Relationship of Yamama Formation (Lower Cretaceous) in Majnoon oil field, Southern- Iraq. A master thesis not published, Baghdad University, (In Arabic), 95pp.

Idan, R. M., Al-Rawi, D., Nasser, M. E., AlMashaekhy, D., 2015a. Reservoir properties and seal efficiency in the Zubair Formation in Euphrates Subzone, Southern Iraq. Arabian Journal of Geosciences, 8(2):773-780.

Idan, R. M., Faisal, R. F., Nasser, M. E., AL-Ameri, T. K., and Al-Rawi, D., 2015 b. Hydrocarbon potential of Zubair Formation in the south of Iraq. Arabian Journal of Geosciences, 8(7):4805-4817.

Idan, R. M., Al-Musawi, F. A., Salih, Amani L. M., Al-Qaraghuli, S. A. F., 2019. The petroleum system of Zubair Formation in Zubair Subzone, Southern Iraq. Journal of Petroleum Research and Studies, (25):E57-E73.

Idan, R. M., and Faisal, R. F., 2019. Application of geophysical logs to estimate the source rock quantity of Ratawi Formation, Southern Iraq: A comparison study. IOP Conf. Ser.: Mater. Sci. Eng. 579:012025. doi.org/10.1088/1757-899X/579/1/012025

Jassim, S. Z., Buday, T., 2006. Late Tithonian - early Turonian Megasequence AP8, Chapter 11, P. 156-183, In Jassim and Goff, editors, Geology of Iraq; Dolin, Prague and Moravian Museum, Brno, 341pp.

López, A. P., and Valera, F. P., 2012. Tempestite facies models for the epicontinental Triassic carbonates of the Betic Cordillera (southern Spain), 59(Issue 2):646-678.

Lucia, F. J., 1995. Rock- fabric/ petrophysical classification of carbonate pore space for reservoir characterization: AAPG Bulletin, 79(9):1275-1300.

Lucia, F. J., Jennings, J. W., 2001. Predicting Permeability from Well Logs in Carbonates with a Link to Geology for Inter-Well Permeability Mapping, SPE, 1-16pp.

Molina, J. M., Ruiz-Ortiz, P.A., and Vera, J. A., 1985. Sedimcntacirn marina somera entre sedimentos pel',tgicos en el Dogger del Subbrtico Externo (Sierras de Cabra y de Puente Genii, provincia de Crrdoba. Trabajos Geologfa Univ. Oviedo, 15:127-146.

Moosavizadeh, S. M. A, Mahboubi, A., Moussavi-Harami, R., Kavoosi, M. A., Schlagintweit, F., 2015. Sequence stratigraphy and platform to basin margin facies transition of the Lower Cretaceous Dariyan Formation (northeastern Arabian Plate, Zagros fold-thrust belt, Iran). Bulletin of Geosciences. Czech Geological Survey, 26:145-72.

Read, J. F. 1985. Carbonate platform Facies models, AAPG Bull., (69):1-21.

Sadooni, F. N., 1993. Stratigraphic sequence, microfacies, and petroleum prospects of the Yamama Formation, Lower Cretaceous, Southern Iraq. The American Association of Petroleum Geologists Bulletin.

Sadooni, F. N., Aqrawi, A. A., 2000, Cretaceous Sequence Stratigraphy and Petroleum Potential of the Mesopotamian Basin, Iraq. SEPM. 315-334pp.

Saller, A. H., Dickson, J. A. D., Matsuda, F., 1999. Evolution and distribution of porosity associated with Subaerial exposure in upper palaeozoic platform Limestone, west Texas, AAPG Bulletin, 83(11):1935-1854.

Sharland, P. R, Archer, R., Casey, D. M., Davies, R. B., Hall, S. H., Heward, A. P., Horbury, A. D., and Simmons, M. D., 2001. Arabian plat sequence stratigraphy, an integrated approach, Geo-Arabia special publication 2 sponsors, $340 \mathrm{pp}$.

Testa, V., and Bosence, D. W. J., 1998. Carbonate-siliciclastic sedimentation on a high-energy, ocean-facing, tropical ramp, NE Brazil. In: Wright, V. P. and Burchette, T. P. (eds) Carbonate Ramps. Geological Society, London, Special Publications, 149:55-71.

Tucker, M. E., 1993. Carbonate diagenesis and sequence stratigraphy in Wright. V. P. ed Sedimentology review/ 1, Oxford, 1:51-72.

Tucker, M. E., 1985: Sedimentary Petrology. An introduction. Blackwell Scientific Publications. 252 pp.

Vaziri, S. H., Fürsich, F. T., Kohansal-Ghadimvand, N., 2012. Facies analysis and depositional environments of the Upper Cretaceous Sadr unit in the Nakhlak area, Central Iran: Revista Mexicana de Ciencias Geológicas, 29(2):384-397.

Yousif, I. M., Abdullatif, O. M., Makkawi, M. H., Bashri, M. A., Abdulghani, W. M., 2018. Lithofacies, paleoenvironment and high-resolution stratigraphy of the D5 and D6 members of the Middle Jurassic carbonates Dhruma Formation, outcrop analog, central Saudi Arabia. Journal of African Earth Sciences, 139:463-479. 